Check for updates

Cite this: RSC Adv., 2019, 9, 31988

Received 1st July 2019

Accepted 9th September 2019

DOI: $10.1039 / c 9 r a 04943 f$

rsc.li/rsc-advances

\section{Tannic acid modulates intestinal barrier functions associated with intestinal morphology, antioxidative activity, and intestinal tight junction in a diquat-induced mouse model}

\author{
Meiwei Wang, ${ }^{\text {ab }}$ Huijun Huang, ${ }^{\text {ab }}$ Shuang Liu, ${ }^{\text {ab }}$ Yu Zhuang, ${ }^{\text {ab }}$ Huansheng Yang, ${ }^{\text {ab }}$ \\ Yali Li, ${ }^{\text {ab }}$ Shuai Chen, iD bc Lixia Wang, ${ }^{\text {ab }}$ Lanmei Yin, $^{\text {ab }}$ Yuanfeng Yao ${ }^{d}$ \\ and Shanping $\mathrm{He}^{\star a}$
}

Oxidative stress is more likely to occur in the intestine compared to other organs because it is located at the interface between an organism and its luminal environment. Tannic acid (TA) is reported to serve as an antioxidant, antimicrobial, anticarcinogenic and antimutagenic agent in various models. In the present study, we evaluated the effects of TA on body weight, intestinal morphology, antioxidative activity, and intestinal barrier in diquat-induced oxidative stress mouse model. The results showed that TA had failed to affect antioxidative enzymes in diquat-challenged mice, while the concentration of $2.5 \mathrm{mg} \mathrm{kg}^{-1}$ to $10 \mathrm{mg} \mathrm{kg}^{-1} \mathrm{TA}$ had no negative effect on body weight and enhanced the colon length in mice. The dose of $2.5 \mathrm{mg} \mathrm{kg}^{-1}$ TA ameliorated the morphological damage in the jejunum by increasing the villus height and crypt depth, activated the antioxidative pathway by decreasing jejunal protein expression of Kelch like-ECH-associated protein 1 (KEAP1) and increasing protein expression of Nuclear factor erythroid 2related factor 2 (NRF2), and affected the intestinal barrier by inhibiting the jejunal mRNA expression of claudin and promoting mRNA expression of zonula occludens (zo-1). In conclusion, the pretreatment of TA in a mouse model of oxidative stress failed to change the antioxidative enzymes but modulated the jejunal morphology, colon length, antioxidative pathway and intestinal barrier in the diquat oxidative model.

\section{Introduction}

Oxidative stress has been widely implicated in the pathology of several human diseases. Oxidative destruction of biological tissue occurs when the antioxidant defense system cannot eliminate the production of excess reactive oxygen species (ROS), such as free radicals. ${ }^{1-3}$ Among the all of organs, the intestine plays a significant role in the absorption of nutrition, however, the intestine sits at the interface between an organism and its luminal environment, and as such is more vulnerable to oxidative damage than other organs because substantial luminal accumulation of diet-derived oxidants, mutagens, carcinogens, and by

${ }^{a}$ Hunan International Joint Laboratory of Animal Intestinal Ecology and Health, Laboratory of Animal Nutrition and Human Health, College of Life Sciences, Hunan Normal University, Changsha, Hunan, 410081, China. E-mail: hesp@hunnu.edu.cn ${ }^{b}$ Chinese Academy of Science, Institute of Subtropical Agriculture, Research Center for Healthy Breeding of Livestock and Poultry, Hunan Engineering and Research Center of Animal and Poultry Science, Key Laboratory for Agroecological Processes in Subtropical Region, Scientific Observation and Experimental Station of Animal Nutrition and Feed Science in South-Central, Ministry of Agriculture, Changsha City, Hunan, 410125, China

${ }^{c}$ University of Chinese Academy of Sciences, Beijing, 10049, China

${ }^{d}$ Wufeng Chicheng Biotechnology Company Limited, Wufeng County, Yichang City, Hubei, 443413, China endogenously generated ROS.4 ${ }^{4-7}$ A growing number of studies have demonstrated that oxidative stress is related to various intestinal diseases, such as the case of intestinal ischemia, inflammatory bowel disease and colorectal cancer. ${ }^{\mathbf{8} 9}$ The understanding of intestinal oxidative stress is progressing, and there are some research studies on new antioxidants from food or natural plants, including polyphenols, flavonoid quercetin, various amino acid, peptides and other natural antioxidatives, to alleviate intestinal oxidative stress. ${ }^{\mathbf{1 0 , 1 1}}$ Therefore, finding more antioxidants is undoubtedly of importance for scavenging intestinal oxidants to protect intestinal health.

One of the oxidative stress models is induced by the intraperitoneally injected diquat, which is widely used to investigate the pathophysiology of oxidative stress and explore the effective therapies. ${ }^{12}$ Diquat is a bipyridyl herbicide which could generate free radicals and variety of highly ROS, thus leading to the cell injury through redox cycling. ${ }^{13}$ Previous studies had proved that diquat-induced oxidative stress damage the small intestine and colon in animal models. ${ }^{\mathbf{1 4 - 1 6}}$ Thus, these characteristics make diquat as an effective chemical agent to induce oxidative stress for studying the anti-oxidant function in intestine.

Tannic acid (TA) is a naturally plant polyphenol including red wine, black tea, green tea and many fruits such as bananas, 
grapes, pears. ${ }^{17}$ TA has antioxidative properties and is similar to other polyphenols. It reacts directly with molecules, or oxidizing to quinones, or ionizing to phenol ions to exert antioxidant effects. ${ }^{18,19}$ For example, TA has been reported to inhibit hydroxyl radical formation and regulate ROS by chelating ferrous ions to alleviate iron-overload induced oxidative stress in liver. $^{20,21}$ TA markedly protects against 1,2 dimethylhydrazine-induced colon toxicity and acts plausibly by virtue of its antioxidant, anti-inflammatory and antiproliferative activities. ${ }^{22}$ Diets supplemented with hydrolysable tannin affected the morphometric traits of the duodenum mucosa but had no effect on other parts of small intestine. ${ }^{23}$ However, few studies have focused on TA as a potential antioxidant agent how to exert influence on jejunum and colon in oxidative stress. This study investigated the effect of TA on growth performance, jejunal and colonic morphology, antioxidative capacity and intestinal barrier function in the diquat-induced mouse model.

\section{Materials and methods}

\subsection{Reagents}

TA (Fig. 1) were procured from Sigma-Aldrich (St. Louis, MO, USA). Diquat were purchased from Toronto Research Chemicals (North York, Canada). Commercially available kits for the analysis of malondialdehyde (MDA), superoxide dismutase (SOD) and catalase (CAT) were purchased from Nanjing Jiancheng Bioengineering Institute (Nanjing, China). Trizol and cDNA Synthesis Kit were purchased from Takara Bioindustry (Tokyo, Japan). SYBR Premix Ex Taq mix was purchased from Thermo Fisher Scientific (Bremen, Germany). RIPA buffer, Bicinchoninic Acid Kit, $5 \times$ loading buffer and horseradish peroxidase-linked secondary antibodies were purchased from Beyotime Biotechnology (Shanghai, China). Primary antibodies against $\beta$-actin, nuclear factor erythroid 2-related factor 2
(NRF2), Kelch like-ECH-associated protein 1 (KEAP1) were obtained from Santa Cruz Biotechnology (CA, USA). PVDF Membranes was purchased from Millipore (Billerica, MA).

\subsection{Animal care and experimental design}

Fifty adult male C57BL/6J mice were purchased from SLAC Laboratory Animal Central (Changsha, China). Animals were housed in rectangular cages (temperature, $22 \pm 2{ }^{\circ} \mathrm{C}$; relative humidity, $50 \pm 5 \%$; lighting cycle, $12 \mathrm{~h} \mathrm{~d}^{-1}$ ) and freely accessed to food and water. As shown in the scheme (Fig. 2), animals were kept in cage for 3 days for adaption. All mice were randomly divided into five groups ( $n=10$ mice per group): (1) control (CON); (2) diquat (DIQ); (3) diquat + $2.5 \mathrm{mg} \mathrm{kg}^{-1}$ tannic acid (LTA); (4) diquat $+5 \mathrm{mg} \mathrm{kg}^{-1}$ tannic acid (MTA); (5) diquat + $10 \mathrm{mg} \mathrm{kg}{ }^{-1}$ tannic acid (HTA). Tannic acid was dissolved in $0.9 \%$ saline solution at the concentrations of $2.5 \mathrm{mg} \mathrm{kg}^{-1}, 5 \mathrm{mg}$ $\mathrm{kg}^{-1}, 10 \mathrm{mg} \mathrm{kg}^{-1}$, respectively. During pretreatment period for 10 days, mice in the diquat $+2.5 \mathrm{mg} \mathrm{kg}^{-1}$, diquat $+5 \mathrm{mg} \mathrm{kg}^{-1}$ and diquat $+10 \mathrm{mg} \mathrm{kg}^{-1}$ groups received at a volume of $0.2 \mathrm{~mL}$ per kg body weight for different concentrations of TA through oral gavage respectively, and recorded the body weight of mice, once a day at 9:00 am. Whereas, mice in the control and diquat groups were pretreated with same volume of $0.9 \%$ saline in same manner. Twelve hours after the last time of gavage, mice in the diquat, diquat $+2.5 \mathrm{mg} \mathrm{kg}^{-1}$, diquat $+5 \mathrm{mg} \mathrm{kg}^{-1}$ and diquat $+10 \mathrm{mg} \mathrm{kg}^{-1}$ groups were intraperitoneally injected with $24 \mathrm{mg} \mathrm{kg} \mathrm{kg}^{-1}$ diquat, while mice in the control group were intraperitoneally injected with the same volume of saline. Another 12 hours later, the length of colon were measured and the samples of jejunum and colon of all groups were collected for further analysis after mice were killed by cervical dislocation. The doses of tannic acid were selected on the basis of a previous study and preliminary studies performed in our laboratory. ${ }^{21}$ All the procedures in this study were approved by

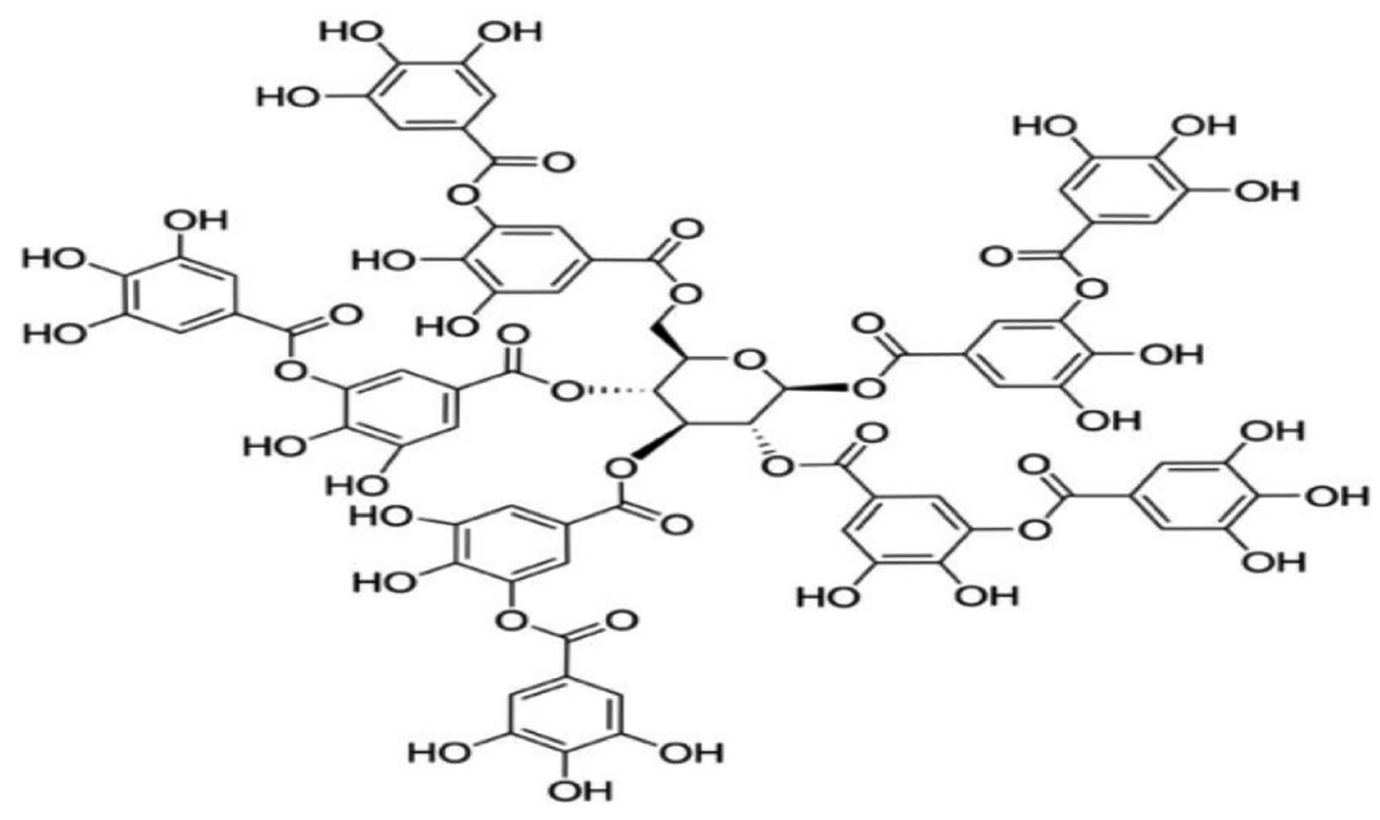

Fig. 1 Chemical structure of tannic acid (TA). 


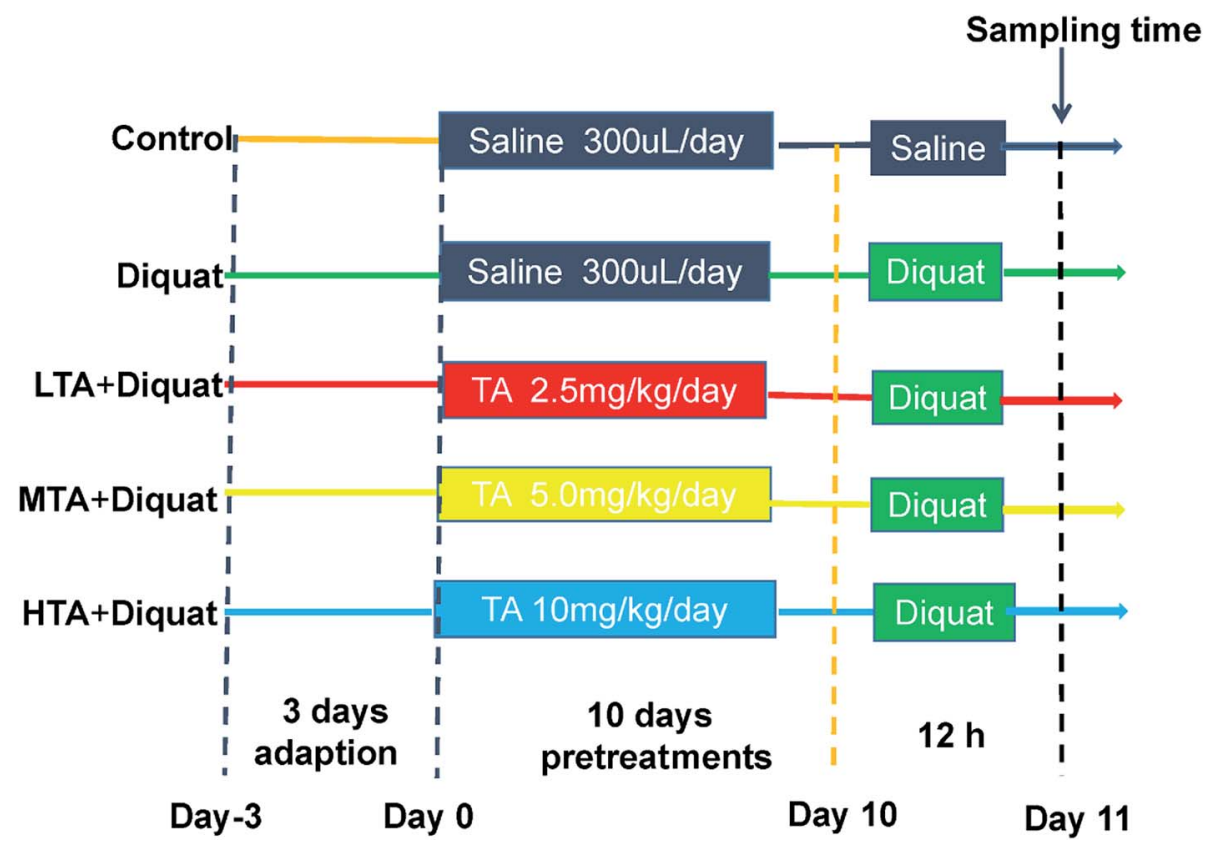

Fig. 2 Scheme of animal treatments.

the Animal Welfare Committee of Hunan Normal University, Changsha City, Hunan, China (No. 2019015). As suggested by the animal welfare protocol, all efforts were made to minimize animal suffering and to use only the number of animals necessary to produce reliable scientific data.

\subsection{Morphology analysis}

Morphology analysis was performed as previous study did. ${ }^{24}$ Briefly, jejunum and colon samples were fixed in $4 \%$ paraformaldehyde solution immediately after sacrificing and embedding in paraffin, three cross sections of each segment were sectioned at $4 \mu \mathrm{m}$ thickness and stained with hematoxylin and eosin (H\&E). Images of the slices were determined under a microscope with $200 \times$ combined magnification, using an image processing and analysis system (Version 1, Leica Imaging Systems Ltd., Cambridge, UK).

\subsection{Determination of MDA concentrations and activity of SOD and CAT}

Tissue samples from the jejunum were homogenized in ice-cold phosphate-buffered saline (137 mM NaCl, $2.7 \mathrm{mM} \mathrm{KCl}, 4.3 \mathrm{mM}$ $\left.\mathrm{Na}_{2} \mathrm{HPO}_{4}, 1.4 \mathrm{mM} \mathrm{KH} \mathrm{PO}_{4}, \mathrm{pH}=7.4\right)$ and centrifuged $(2500 \times g$, $4{ }^{\circ} \mathrm{C}, 10 \mathrm{~min}$ ). The MDA concentrations and enzymatic activities of SOD and CAT were determined using commercially available kits according to the manufactures' instructions (Nanjing Jiancheng Bioengineering Institute, Nanjing, China). Briefly, a CAT detection kit (the ammonium molybdate method), an SOD detection kit (the hydroxylamine method), an MDA detection kit (the thiobarbituric acid method) were used to determine the CAT activity, the SOD activity, and the MDA concentrations, respectively.

\subsection{Gene expression analysis by qPCR}

Total RNA was isolated from liquid nitrogen-frozen ground jejunum samples with the TRIZOL reagents (Takara) and then transcripted by cDNA Synthesis Kit (Takara) according to the manufacturer's instruction. Primers were designed with NCBI online website to produce amplification products (Table 1). The $\beta$-actin was used to normalize target gene transcript levels. qPCR was performed as previous study did. ${ }^{25}$ Briefly, $1 \mu \mathrm{L}$ cDNA

Table 1 Primers used in this study

\begin{tabular}{|c|c|c|}
\hline & Nucleotide sequence of primers $\left(5^{\prime}-3^{\prime}\right)$ & Product length \\
\hline \multirow[t]{2}{*}{ SOD } & GGTGAACCAGTTGTGTTGTCAGG & 114 \\
\hline & ATGAGGTCCTGCACTGGTACAG & \\
\hline \multirow[t]{2}{*}{ GPX } & CGCTCTTTACCTTCCTGCGGAA & 120 \\
\hline & AGTTCCAGGCAATGTCGTTGCG & \\
\hline \multirow[t]{2}{*}{ GCLM } & TCCTGCTGTGTGATGCCACCAG & 113 \\
\hline & GCTTCCTGGAAACTTGCCTCAG & \\
\hline \multirow[t]{2}{*}{ NRF2 } & CAGCATAGAGCAGGACATGGAG & 107 \\
\hline & GAACAGCGGTAGTATCAGCCAG & \\
\hline \multirow[t]{2}{*}{ KEAP1 } & ATCCAGAGAGGAATGAGTGGCG & 123 \\
\hline & TCAACTGGTCCTGCCCATCGTA & \\
\hline \multirow[t]{2}{*}{ NQO1 } & GCCGAACACAAGAAGCTGGAAG & 120 \\
\hline & GGCAAATCCTGCTACGAGCACT & \\
\hline \multirow[t]{2}{*}{ HO-1 } & CACTCTGGAGATGACACCTGAG & 115 \\
\hline & GTGTTCCTCTGTCAGCATCACC & \\
\hline \multirow[t]{2}{*}{ CLAUDIN } & GAAAAATGGACGAACTGGGCTCC & 150 \\
\hline & CCAGAACGGAGGCAGCAATCAT & \\
\hline \multirow[t]{2}{*}{ OCCLUDIN } & TGGCAAGCGATCATACCCAGAG & 103 \\
\hline & CTGCCTGAAGTCATCCACACTC & \\
\hline \multirow[t]{2}{*}{ ZO-1 } & GTTGGTACGGTGCCCTGAAAGA & 133 \\
\hline & GCTGACAGGTAGGACAGACGAT & \\
\hline \multirow[t]{2}{*}{ ACTIN } & CATTGCTGACAGGATGCAGAAGG & 138 \\
\hline & TGCTGGAAGGTGGACAGTGAGG & \\
\hline
\end{tabular}


template was added to a total volume of $10 \mu \mathrm{L}$ assay solution containing $5 \mu \mathrm{L}$ SYBR Green mix (Thermo Scientific, USA), 3.4 $\mu \mathrm{L}$ deionized $\mathrm{H}_{2} \mathrm{O}$, and $0.3 \mu \mathrm{L}$ each of forward and reverse primers. The relative quantification of gene expression was analyzed using the $2^{-\Delta \Delta C_{t}}$ method and $\beta$-actin served as an internal control. All samples were run in triplicate and the average values were calculated.

\subsection{Western blotting analysis}

Western blot analysis was performed as previously described. ${ }^{25}$ Total protein of jejunal mucosa was lysed in ice-cold RIPA buffer (150 mM NaCl, 1\% Triton X-100, 0.5\% sodium deoxycholate, 0.1\% SDS, 50 mM Tris-HCl; pH 7.4) (Beyotime Biotechnology, Shanghai, China) with protease inhibitor cocktail (Beyotime Biotechnology, Shanghai, China). The supernatants were obtained through centrifugation $\left(12000 \mathrm{rpm}, 4{ }^{\circ} \mathrm{C}, 10 \mathrm{~min}\right)$, and protein concentration was determined using a Bicinchoninic Acid assay following the manufacturer's instructions (Beyotime Biotechnology). All samples were adjusted to an equal protein concentration, then diluted with $5 \times$ loading buffer (Beyotime Biotechnology) to a final volume of $1 \mathrm{~mL}$ and heated in boiling water for $10 \mathrm{~min}$. Protein samples were separated by SDS-PAGE (sodium dodecyl sulfate polyacrylamide gel electrophoresis) gels and transferred to PVDF membranes (Millipore, Billerica, MA). They were blocked with 5\% nonfat milk in TBS-0.05\% Tween-20 for $1 \mathrm{~h}$ and incubated overnight with primary antibodies followed by horseradish peroxidase-linked secondary antibodies (Beyotime Biotechnology). The abundance of the target proteins were normalized by $\beta$-actin, and AlphaImager 2200 software (Alpha Innotech Corporation, CA, USA) was used to quantify the bands of each protein per sample. Protein bands were detected using an ECL Advanced Kit (Amersham Biosciences, Buckinghamshire, UK). $\beta$-Actin antibodies were used to verify the equal loading of samples.

\subsection{Statistical analysis}

All statistical analyses were subjected to one-way ANOVA using SPSS software (Version 22; SPSS Inc., Chicago, USA). Differences among treatment means were determined using Duncan's range test. Data were presented as mean \pm SEM, and $P$-values < 0.05 were used to indicate statistical significance.

\section{Results}

\subsection{Effect of TA on body weight}

It was explored whether different concentrations of TA affected the body weight of the mice. When mice were oral administered with the dosage of $2.5 \mathrm{mg} \mathrm{kg}{ }^{-1}, 5 \mathrm{mg} \mathrm{kg}^{-1}$, and $10 \mathrm{mg} \mathrm{kg}{ }^{-1} \mathrm{TA}$ every day, there were no significant difference in the body weight compared with the control group and DIQ group (Fig. 3).

\subsection{Effect of TA on jejunal morphology}

It was investigated whether TA relieves oxidative stress by improving jejunal morphology, we investigated the jejunal morphology of villus height, crypt an the $\mathrm{VH}$ : $\mathrm{CD}$ ratio. As showed in Fig. 4A, jejunal villus of control mice showed orderly

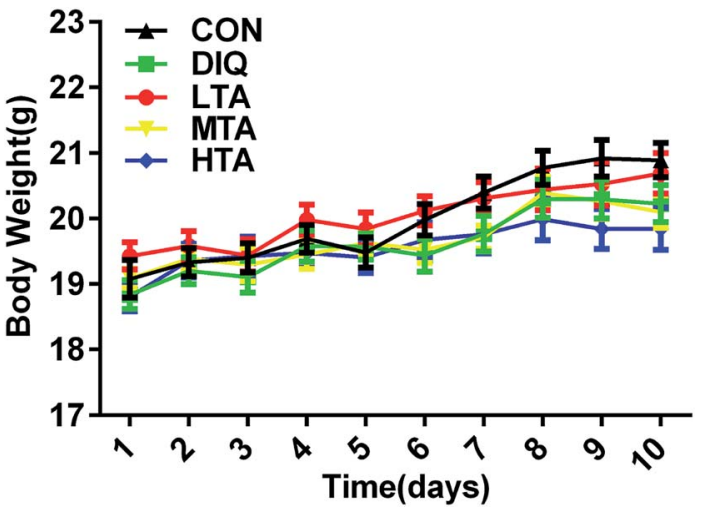

Fig. 3 Effect of tannic acid (TA) on body weight in mice. CON, control mice; DIQ, diquat-treated mice; LTA, mice pretreated with $2.5 \mathrm{mg} \mathrm{kg}^{-1}$ TA and treated with diquat; MTA, mice pretreated with $5 \mathrm{mg} \mathrm{kg}^{-1}$ TA and treated with diquat; HTA, mice pretreated with $10 \mathrm{mg} \mathrm{kg}^{-1} \mathrm{TA}$ and treated with diquat; values are expressed as mean $\pm \operatorname{SEM}, n=10$.

arranged intestinal epithelial cells and smooth villus border (red arrows), whereas the DIQ group showed atrophied villus, zigzag brush border and disorderly epithelium (red arrows), the jejunal morphology of LTA pretreated mice were as intact as mice in the control group (red arrows). Barely protective effect could be observed in the MTA and HTA pretreated mice, as shown by the discontinuous villus (red arrows). Compared with mice in control group, jejunal villus height $(\mathrm{VH})$ in DIQ group were significantly decreased. Compared with mice in DIQ group, villus height and crypt depth (CD) were significantly higher when they were treated with LTA, while no significant difference in villus height was observed in MTA and HTA group (Fig. 4B and C). However, the pretreatment with MTA and HTA had significantly decreased the VH : CD ratio than that of LTApretreated mice (Fig. 4D).

\subsection{Effect of TA on colonic length and morphology}

The effects of different TA concentrations on colonic length and morphology in diquat-induced mice were showed in the Fig. 5A. Compared with the control group and the DIQ group, different TA concentrations evidently increased colon length (Fig. 5B). The result showed that the MTA and HTA groups resulted in colonic crypt marked difference compared with LTA and diquattreated mice (Fig. 5C). No significant difference in colonic goblet cells were observed between mice in DIQ group and mice in different dose of TA group (Fig. 5D).

\subsection{Effect of TA on jejunal redox balance}

To verify whether TA ameliorate oxidative stress through activating antioxidative system in the diquat-induced oxidative stress model, we investigated the activity and the gene expression of antioxidative enzymes and oxidation products. The results showed that MTA and HTA pretreatment strongly stimulated the activity of superoxide dismutase (SOD) compared with diquat treated mice (Fig. 6B), but catalase (CAT) had no significant difference by different concentration TA pretreatment (Fig. 6A). Moreover, the TA pretreated mice did not result 

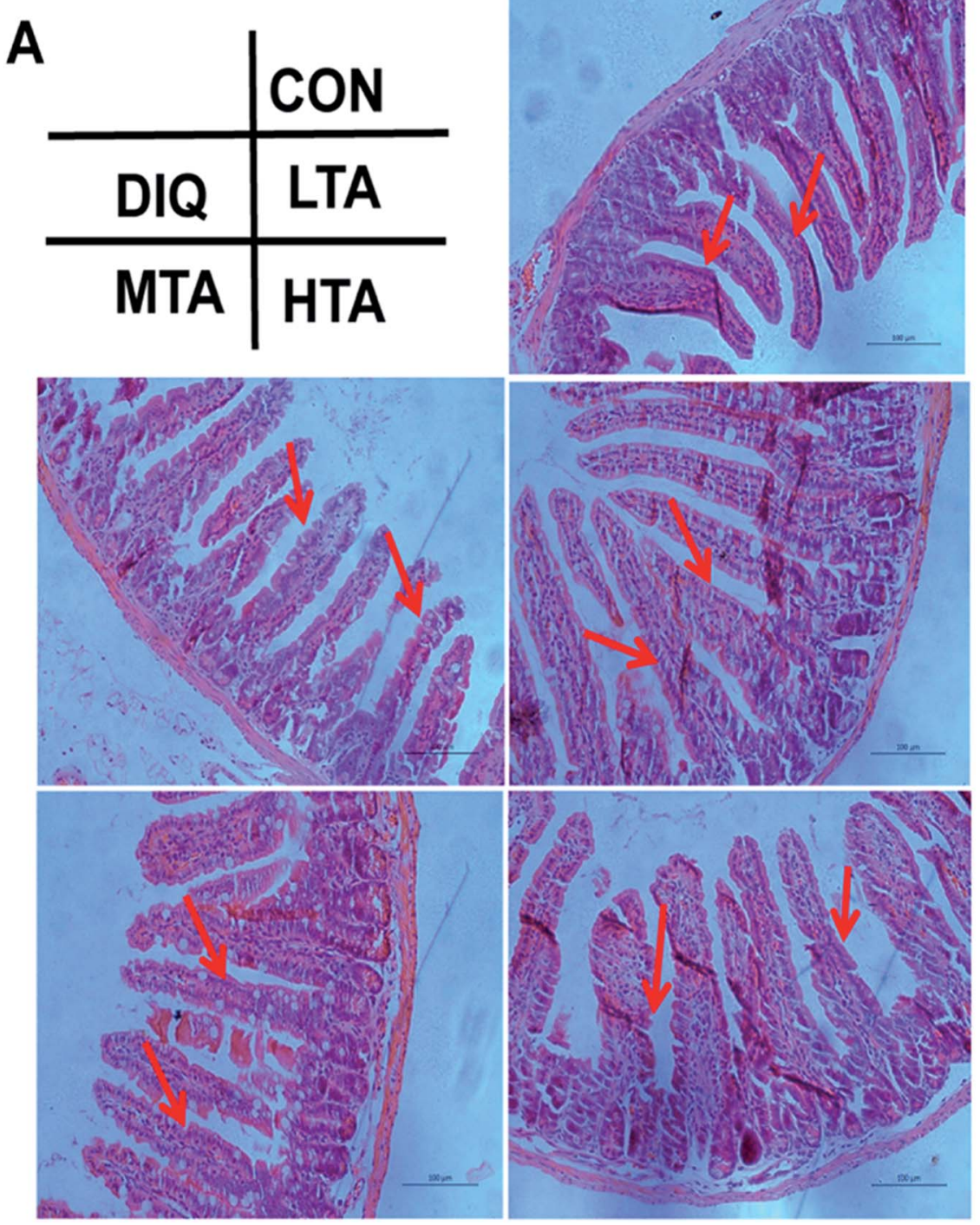
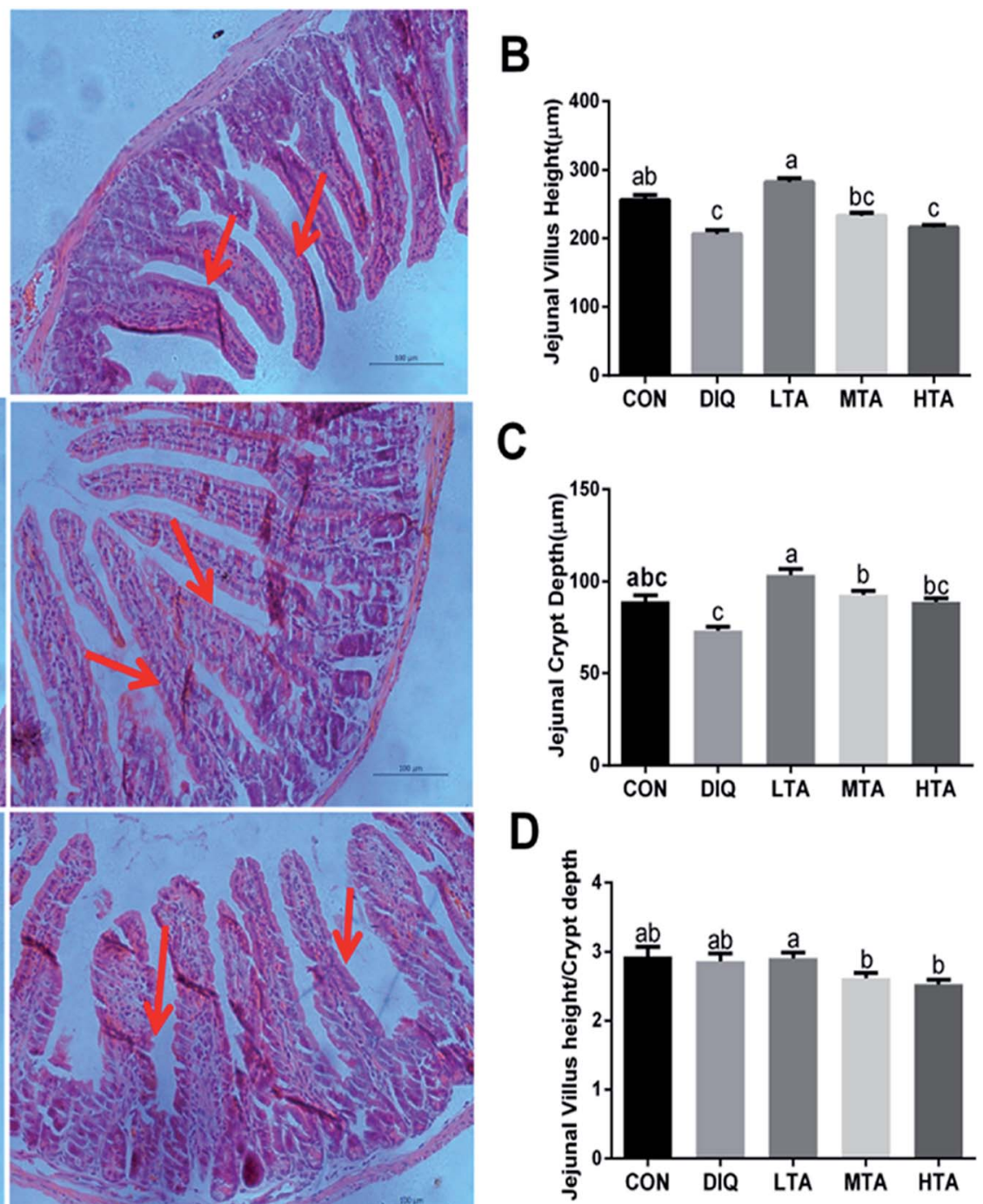

Fig. 4 Effect of tannic acid (TA) on jejunal morphology in diquat-induced mice. CON, control mice; DIQ, diquat-treated mice; LTA, mice pretreated with $2.5 \mathrm{mg} \mathrm{kg}^{-1} \mathrm{TA}$ and treated with diquat; MTA, mice pretreated with $5 \mathrm{mg} \mathrm{kg}^{-1} \mathrm{TA}$ and treated with diquat; HTA, mice pretreated with $10 \mathrm{mg} \mathrm{kg}^{-1} \mathrm{TA}$ and treated with diquat; (A) representative Images of the jejunum morphology were observed at $200 \times$ magnification. (B) Villus height in jejunum. (C) Crypt depth in jejunum. (D) The ratio of villus height and crypt depth. Values are expressed as mean \pm SEM, $n=10$. a,b Means of the bars with different letters were significantly different among groups $(P<0.05)$.

marked difference in the oxidation products of malondialdehyde (MDA) compared with diquat-only treated mice but LTApretreated mice tended to decreased the concentration of MDA (Fig. 6C). In addition, compared with mice in the DIQ group, mRNA expression of genes encoding SOD and glutamatecysteine ligase regulatory subunit (GCLM) were slightly higher in TA pretreated mice, while mRNA expression of gene encoding glutathione peroxidase (GPX) was slightly lower (Fig. 6D-F), although the difference were not statistically significant.

\subsection{Effect of TA on mRNA expression of Nrf2-keap1 pathway}

To further investigate whether TA activates Nrf2-keap1 pathway to attenuate oxidative stress induced by diquat in mice, we investigated the gene expression and protein expression of Nrf2keap1 pathway. The results showed that LTA-pretreated mice tended to decrease the protein expression of KEAP1 and increase the protein expression of NRF2 (Fig. 7E-G). However, the gene expression of nuclear factor erythroid 2-related factor 2 (NRF2), Kelch like-ECH-associated protein 1 (KEAP1), NADPH dehydrogenase (NQO-1), Heme oxygenase (HO-1) of TApretreated mice tended to increase than that of diquat group (Fig. 7A-D), although there was no statistically significant difference.

\subsection{Effect of TA on mRNA expression of intestinal barrier}

In order to futher illustrate whether TA enhances intestinal barrier in diquat-induced mice, the gene expression of tight junction was detected. As showed in Fig. 8, compared with the diquat-only treated mice, the HTA group significantly decreased the mRNA expression of claudin, while the LTA and MTA groups 

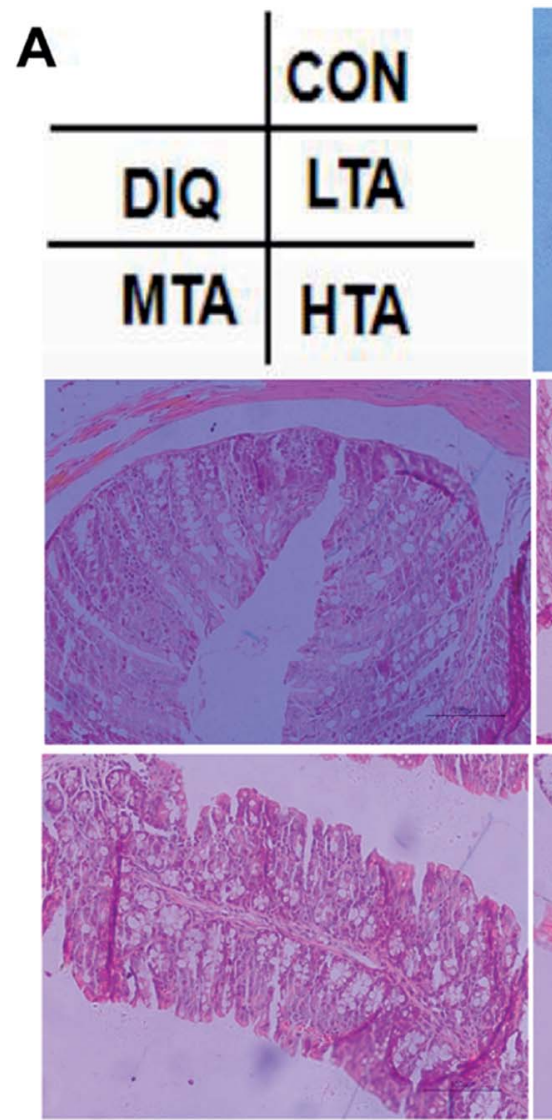
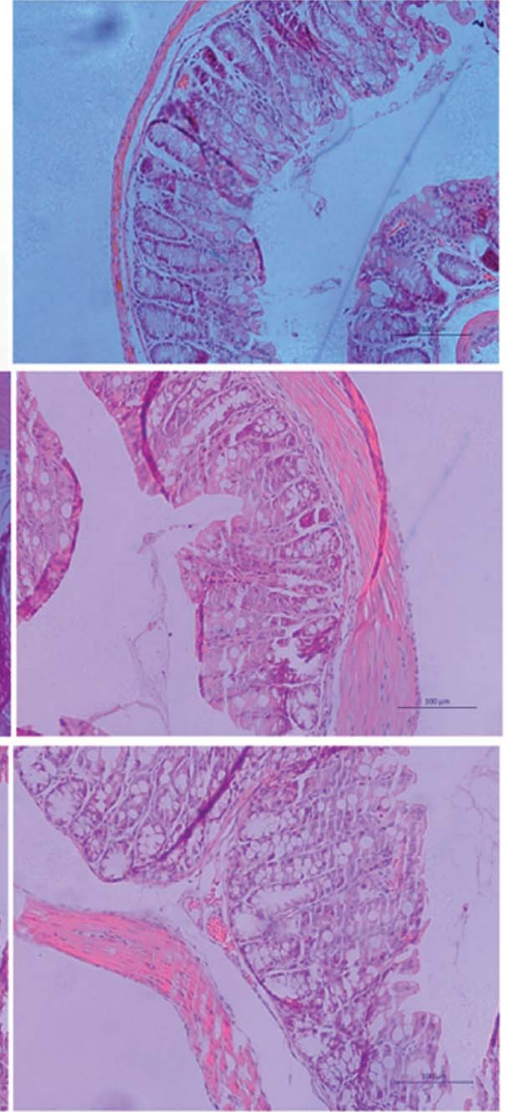

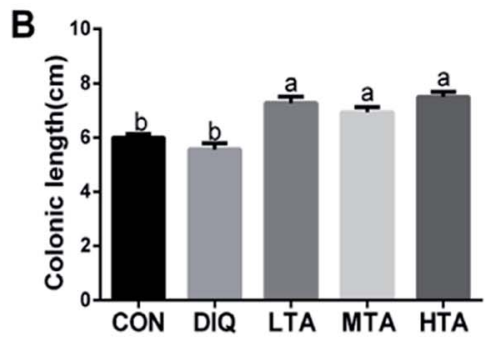

C
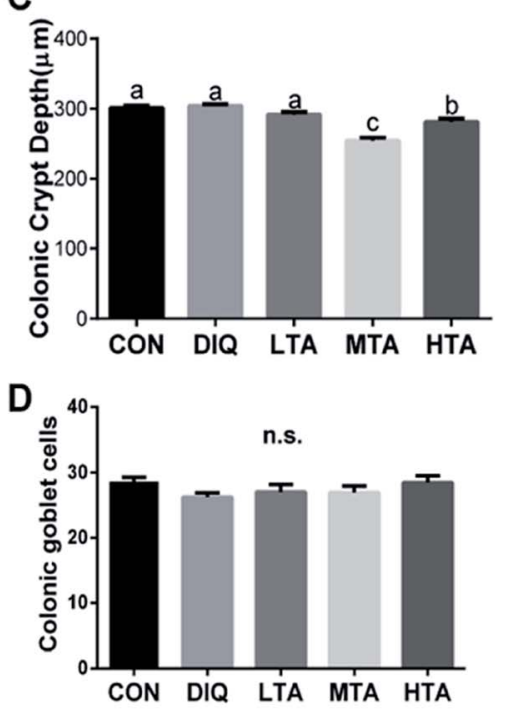

Fig. 5 Effect of tannic acid (TA) on colonic morphology in diquat-induced mice. CON, control mice; DIQ, diquat-treated mice; LTA, mice pretreated with $2.5 \mathrm{mg} \mathrm{kg}^{-1} \mathrm{TA}$ and treated with diquat; MTA, mice pretreated with $5 \mathrm{mg} \mathrm{kg}^{-1} \mathrm{TA}$ and treated with diquat; HTA, mice pretreated with $10 \mathrm{mg} \mathrm{kg}^{-1} \mathrm{TA}$ and treated with diquat; (A) representative images of the colon morphology were observed at $200 \times$ magnification. (B) Colon length in colon. (C) Crypt depth in colon. (D) Goblet cells of per crypt in colon. Values are expressed as mean \pm SEM, $n=10$. ${ }^{a, b}$ Means of the bars with different letters were significantly different among groups $(P<0.05)$.

significantly increased the mRNA expression of zonula occludens 1 (zo-1). No significant difference in the mRNA expression of occludin was observed between mice in DIQ group and mice pretreated with TA.

\section{Discussion}

Tannins can be divided into two categories: hydrolyzable and condensed tannins. Hydrolyzable tannins contain a central core of polyhydric alcohol such as glucose, and hydroxyl groups, which are esterified either partially or wholly by gallic acid (gallotannins). Gallotannis have many species, including Chinese tannin (tannic acid), Turkish tannin, Tara tannin, Acer tannin, and Hamamelis tannin. In the present study, we used Chinese tannin (tannic acid) to investigate the effect of body weight, intestinal morphology, antioxidative capacity and intestinal barrier in diquat-induced mice, which is extracted from nutgall contained a glucose linking through ester bonds to an average of nine to ten molecules of gallic acid.

An increasing amount of evidences have demonstrated that TA has multiple biological activities, including its antioxidant, anti-inflammatory, antimicrobial, antimutagenic effects. ${ }^{17,18,26}$
However, TA has been considered to have the antinutritional activity, owing to the fact that it forms complexes with proteins, starch and digestive enzymes and reduce the nutritional values of foods. ${ }^{26}$ Lee and colleagues demonstrated that pigs supplemented with 125, 250, 500 and $1000 \mathrm{mg}$ TA per $\mathrm{kg}$ diet had 2, 21, 28 and $25 \%$ lower ADG, and 0.4, 9, 16, and $15 \%$ less feed intake than pigs without TA supplementation. ${ }^{27}$ Mariscal-Landín found that tannis levels up to $4 \%$ reduce the digestibility of dietary protein in growing pigs. ${ }^{28}$ In the present study, no negative effects on growth performance were found in $2.5 \mathrm{mg}$ $\mathrm{kg}^{-1}, 5 \mathrm{mg} \mathrm{kg}{ }^{-1}$ and $10 \mathrm{mg} \mathrm{kg}^{-1}$ TA-pretreated mice, indicating that pretreatment of $2.5 \mathrm{mg} \mathrm{kg}^{-1}$ to $10 \mathrm{mg} \mathrm{kg}^{-1} \mathrm{TA}$ in mice do not have antinutritional effects. These results were in line with previous studies showing that dietary supplementation with a small quantity of the right kind of tannis may have no effect on growth performance. ${ }^{29}$ Thus, our study determined the safe dose of $2.5 \mathrm{mg} \mathrm{kg}^{-1}$ to $10 \mathrm{mg} \mathrm{kg}{ }^{-1}$ of Chinese tannin (tannic acid) in mice experiment.

Injection of diquat resulted in a decrease of villus height in the jejunum and ileum as well as in villus width and crypt depth in the duodenum, jejunum and ileum in weaned pigs. ${ }^{30}$ Consistent with these findings, our results showed that 
A
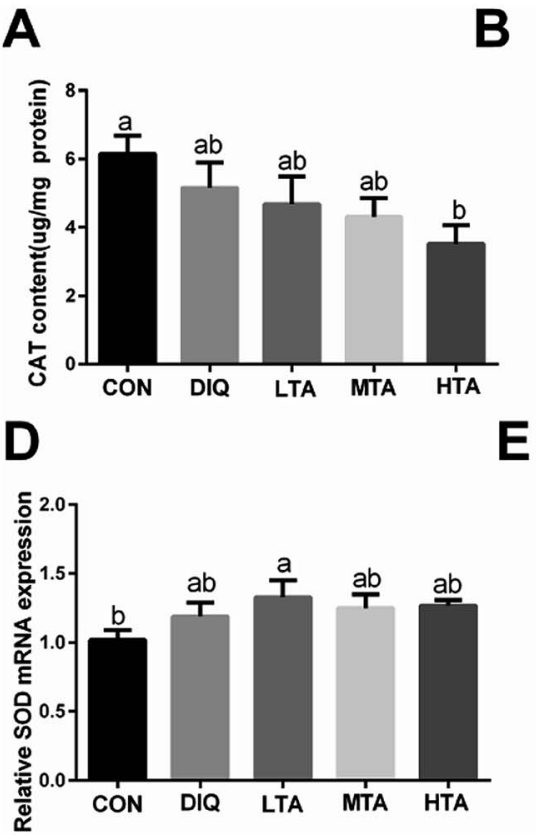

B
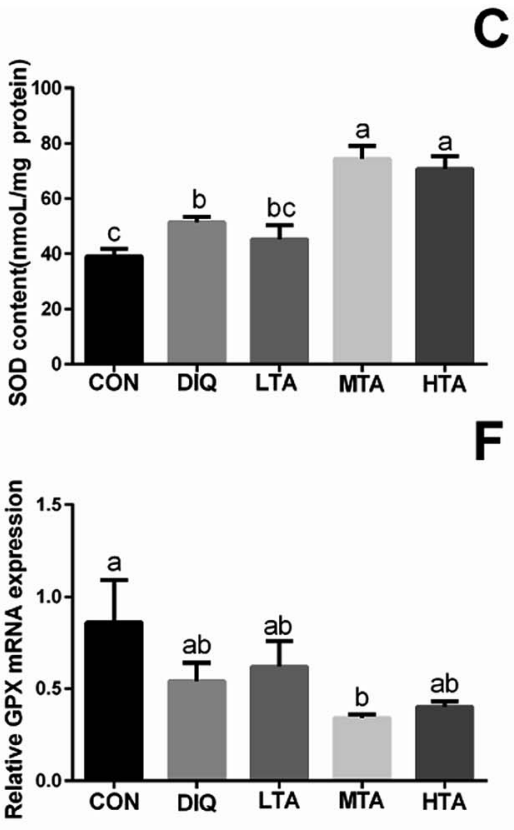

C
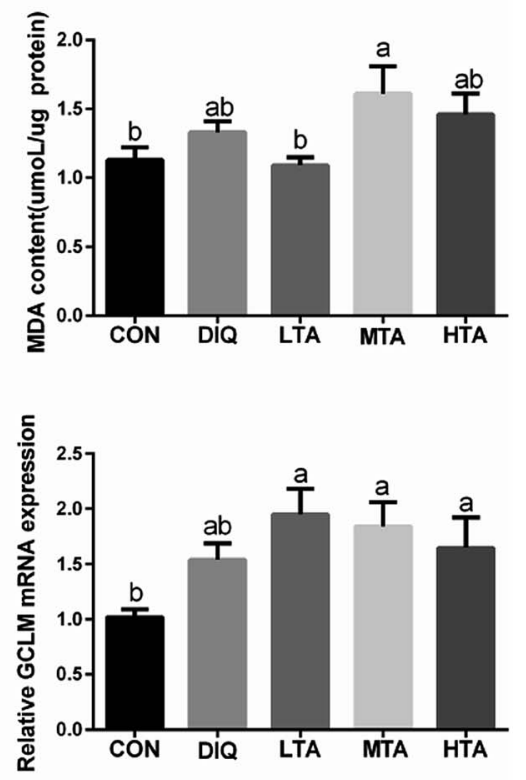

Fig. 6 Effect of tannic acid (TA) on jejunal redox balance in diquat-induced mice. CON, control mice; DIQ, diquat-treated mice; LTA, mice pretreated with $2.5 \mathrm{mg} \mathrm{kg}^{-1} \mathrm{TA}$ and treated with diquat; MTA, mice pretreated with $5 \mathrm{mg} \mathrm{kg}^{-1} \mathrm{TA}$ and treated with diquat; HTA, mice pretreated with $10 \mathrm{mg} \mathrm{kg}^{-1} \mathrm{TA}$ and treated with diquat; (A) Catalase (CAT) content in jejunum (B) Superoxide dismutase (SOD) content in jejunum. (C) Malondialdehyde (MDA) in colon. (D)-(F) The gene expression of SOD, Glutathione peroxidase (GPX), Glutamate-cysteine ligase regulatory subunit (GCLM) in jejunum. Values are expressed as mean $\pm \mathrm{SEM}, n=10$. ${ }^{\mathrm{a}, \mathrm{b}}$ Means of the bars with different letters were significantly different among groups $(P<0.05)$.

oxidative stress induced by diquat significantly decreased villus height and crypt depth in the jejunum. Pretreatment with $2.5 \mathrm{mg} \mathrm{kg}^{-1}$ TA significantly mitigated jejunum villus atrophy, pretreatment with $2.5 \mathrm{mg} \mathrm{kg}^{-1}$ and $5 \mathrm{mg} \mathrm{kg}^{-1} \mathrm{TA}$ strongly increased jejunum crypt depth but pretreatment with $10 \mathrm{mg}$ $\mathrm{kg}^{-1}$ TA damaged jejunal morphology as same as DIQ group. Study has demonstrated that small amounts of TA reduced the comparative aggression of this substance on the digestive mucosa and mucus hypersecretion, and stimulated enterocyte proliferation in the middle of the crypt zone of the jejunum. ${ }^{31}$ However, large dose tannin-fed animals indicated epithelial degeneration and ulceration in the jejunum and ileum..$^{32}$ Thus, the concentration of $2.5 \mathrm{mg} \mathrm{kg}^{-1}$ TA might alleviate the oxidative stress induced by diquat to regulate jejunal morphology (villus height and crypt depth) injury, but $10 \mathrm{mg} \mathrm{kg}^{-1}$ TA had adverse effect to jejunal morphology.

Histological parameters reflect intestinal environment and are an indication of health status. ${ }^{33} \mathrm{M}$. Barszcz and colleagues reported that TA affected colonic myenteron thickness and adding TA to the diets did not alter the colon crypt depth of rats. ${ }^{34-36} \mathrm{TA}$ is toxic to animals when injected into the blood stream or ingested in large doses but in small amounts tannic acid has a health-promoting action. ${ }^{37}$ In this study, we found that mice-pretreated with TA had significantly increased colon length compared with control group but $5 \mathrm{mg} \mathrm{kg}{ }^{-1}, 10 \mathrm{mg} \mathrm{kg}^{-1}$ TA group reduced colonic crypt depth. TA-pretreated mice had no significantly difference on colonic goblet cells compared to DIQ group. This might be because TA affected colonic myenteron thickness to increase colon length, but the decreased crypt depth might be caused by higher dosage of TA. Therefore, it can be assumed that TA pretreated mice can boost the colon length in mice but does not influence colonic morphology to ameliorate oxidative stress.

Antioxidants can also protect the human body from free radicals and ROS effects. ${ }^{11}$ It was reported that the polyphenolic nature of tannic acid, it's relatively hydrophobic "core" and hydrophilic "shell" are the features responsible for its antioxidant action. ${ }^{38}$ However, higher concentrations of TA (40 and 60 $\mathrm{mM}$ ) were toxic, thus enhancing Cd-mediated cytotoxic and oxidative effects. ${ }^{39}$ It would be activated antioxidative enzymes when the human body had been damaged by oxidative stress. ${ }^{40}$ The enzyme-containing group is composed of direct-acting proteins, such as SOD, which is capable of enhancing the spontaneous dismutation of superoxide radicals to hydrogen peroxide $\left(\mathrm{H}_{2} \mathrm{O}_{2}\right)$ and molecular oxygen. Then, the end product of the dismutation reaction $\left(\mathrm{H}_{2} \mathrm{O}_{2}\right)$ can be removed by the activity of the enzyme catalase and members of the peroxidase family including glutathione peroxidase (GPX). ${ }^{41}$ The mRNA expression of GCLM increases in response to oxidative stress. ${ }^{42}$ The level of MDA, which is a major product of lipid peroxidation. In the present study, there was a tendency to decrease the content of jejunal CAT, SOD and MDA in $2.5 \mathrm{mg} \mathrm{kg}^{-1} \mathrm{TA}$ pretreated mice, but a tendency to increase jejunal SOD and MDA content with $5 \mathrm{mg} \mathrm{kg}^{-1}, 10 \mathrm{mg} \mathrm{kg}^{-1} \mathrm{TA}$ group compared to DIQ group was observed. We also observed no significant difference in mRNA expression of SOD, GPX, GCLM between TA 


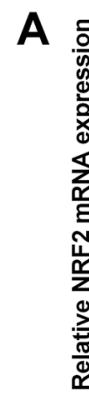

C
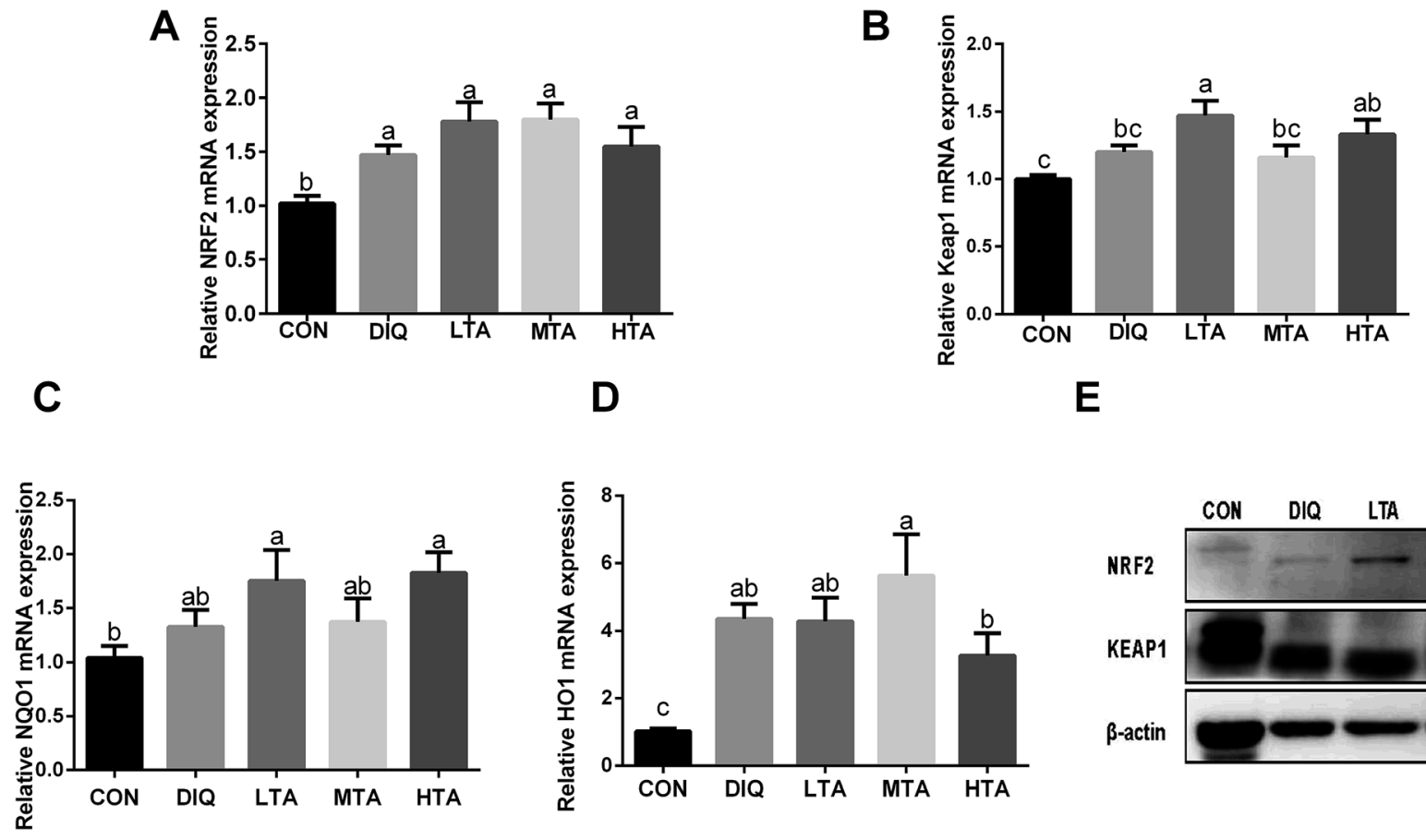

E
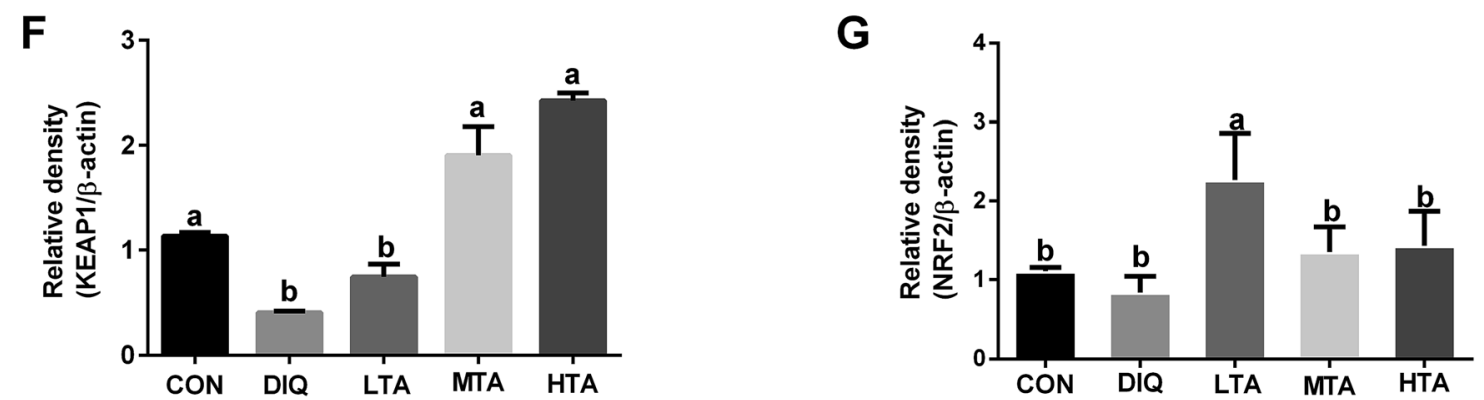

Fig. 7 Effect of tannic acid (TA) on Nrf2-keap1 pathway in diquat-induced mice. CON, control mice; DIQ, diquat-treated mice; LTA, mice pretreated with $2.5 \mathrm{mg} \mathrm{kg}^{-1} \mathrm{TA}$ and treated with diquat; MTA, mice pretreated with $5 \mathrm{mg} \mathrm{kg}^{-1} \mathrm{TA}$ and treated with diquat; HTA, mice pretreated with $10 \mathrm{mg} \mathrm{kg}^{-1} \mathrm{TA}$ and treated with diquat; (A)-(D) the gene expression of nuclear factor erythroid 2-related factor 2 (NRF2), Kelch like-ECHassociated protein 1 (KEAP1), NADPH dehydrogenase (NQO-1), heme oxygenase (HO-1) in jejunum. (E) The protein expression of NRF2, KEAP-1 and $\beta$-actin. (F) and (G) The protein expression of KEAP1, NRF2 in jejunum. Values are expressed as mean $\pm \mathrm{SEM}, n=10$. ${ }^{\mathrm{a}, \mathrm{b}}$ Means of the bars with different letters were significantly different among groups $(P<0.05)$.

A

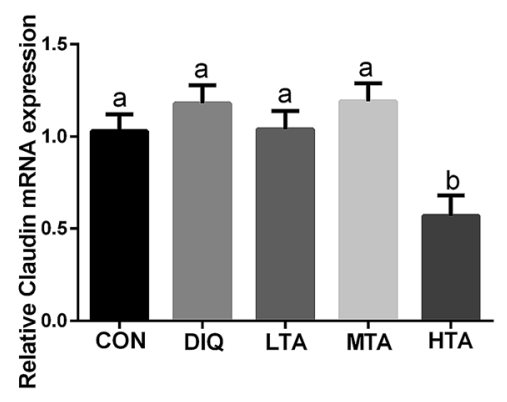

B

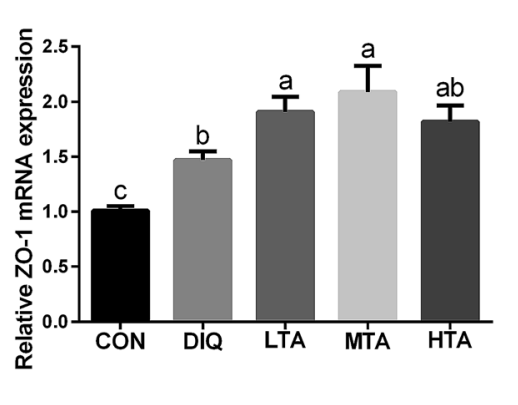

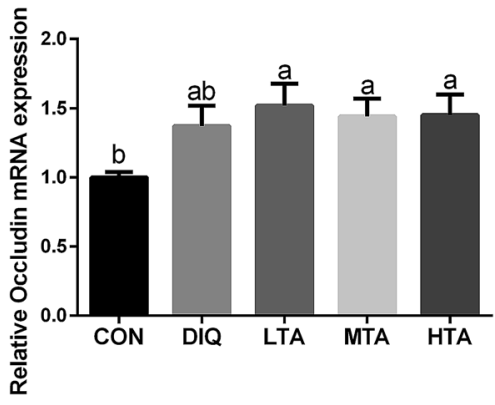

Fig. 8 Effect of tannic acid (TA) on intestinal barrier in diquat-induced mice. CON, control mice; DIQ, diquat-treated mice; LTA, mice pretreated with $2.5 \mathrm{mg} \mathrm{kg}^{-1} \mathrm{TA}$ and treated with diquat; MTA, mice pretreated with $5 \mathrm{mg} \mathrm{kg}^{-1} \mathrm{TA}$ and treated with diquat; HTA, mice pretreated with $10 \mathrm{mg}$ $\mathrm{kg}^{-1} \mathrm{TA}$ and treated with diquat; (A)-(C) the gene expression of claudin, zonula occludens 1 (zo-1), occludin in jejunum. Values are expressed as mean $\pm \mathrm{SEM}, n=10$. ${ }^{\mathrm{a}, \mathrm{b}}$ Means of the bars with different letters were significantly different among groups $(P<0.05)$. 
pretreated mice and diquat-induced mice. Our results did not be consistent with other studies, ${ }^{20-22}$ this might be because large dose TA had the pro-oxidative effect to jejunum and $2.5 \mathrm{mg} \mathrm{kg} \mathrm{kg}^{-1}$ pretreatment-TA did not affect jejunal antioxidative enzymes and antioxidative genes to alleviate oxidative stress.

$\mathrm{Nrf} 2$ is a key factor to regulate the induction of genes encoding antioxidant proteins and phase 2 detoxifying enzymes. ${ }^{43}$ Nrf2 remains in the cytoplasm bound to Keap1, which is rapidly degraded by the ubiquitin-proteasome pathway under normal conditions. ${ }^{44}$ When cells are stimulated by free radicals and reactive oxygen species, $\mathrm{Nrf} 2$ was dissociated from Nrf2-keap1 complex, then stabilized Nrf2 translocates to the nuclei and leading to the activation of its target genes (NQO-1 and HQ-1). ${ }^{45}$ In the present study, the results showed that diquat-induced oxidative stress disturbed the Nrf2-keap1 signaling pathway, while was activated by LTA pretreatment. These results were in a same tendency with previous results showing that $2.5 \mathrm{mg} \mathrm{kg}^{-1}$ TA pretreated mice can relieve jejunal morphology damage by diquat-induced oxidative stress. However, we found that mRNA expression of Nrf2, NQO-1 and HO-1 had no significance between TA-pretreated mice and DIQ mice despite $2.5 \mathrm{mg} \mathrm{kg}{ }^{-1}$ TA-pretreated group had promoted the gene expression of keap1. This might because transcription and translation are different timings, spots of action and mechanisms of regulation to control the gene expression. It is indicating that $2.5 \mathrm{mg} \mathrm{kg}{ }^{-1}$ pretreated TA might activate Nrf2keap1 pathway to attenuate oxidative stress, while $5 \mathrm{mg} \mathrm{kg}^{-1}$ and $10 \mathrm{mg} \mathrm{kg}^{-1}$ pretreated TA might have no effect on Nrf2keap1 pathway.

Intestinal epithelial cells are a major component of the intestinal epithelium, which are jointed by tight junctions (occludin, zo-1 and claudin) to form the epithelial barrier. ${ }^{46}$ Diquat treatment damaged the intestinal barrier in mice, which resulted in discontinuous intestinal brush borders and disorder epithelium. ${ }^{47}$ We observed that $10 \mathrm{mg} \mathrm{kg}^{-1}$ pretreated TA had significantly inhibited the mRNA abundance of claudin and $2.5 \mathrm{mg} \mathrm{kg}^{-1}$ and $5 \mathrm{mg} \mathrm{kg}^{-1} \mathrm{TA}$ group had significantly promoted the mRNA expression of zo-1, but TA pretreated mice failed to regulate the gene expression of occludin. This might be due to the increase the mRNA expression of zo- 1 in TA pretreated mice as an antioxidative response of the body to balance intestinal epithelial barrier, and the pretreatment of TA enhanced the intestinal barrier, thus, resulted to reduce the gene expression of occludin in oxidative stress.

\section{Conclusions}

The doses of $2.5 \mathrm{mg} \mathrm{kg}^{-1}$ to $10 \mathrm{mg} \mathrm{kg}^{-1} \mathrm{TA}$ pretreatment had no negative effects on body weight and promoted colon length in mice. The concentration of $2.5 \mathrm{mg} \mathrm{kg}^{-1}$ TA pretreated mice can improve jejunum morphology, activate Nrf2-keap1 pathway, and promote the gene expression of Keap1 and zo-1 to ameliorate diquat-induced jejunal injury. In addition, $5 \mathrm{mg}$ $\mathrm{kg}^{-1}$ and $10 \mathrm{mg} \mathrm{kg}^{-1}$ pretreated TA had a prooxidative effect to jejunum and colon morphology. These finding help to the understanding of the roles of TA in the body weight, colon length, jejunum and colon morphology in mice.

\section{Author's contribution}

Meiwei Wang and Shanping He designed the experiment. Meiwei Wang, Huijun Huang, Shuang Liu, Yu Zhuang and Yuanfeng Yao conducted the experiment. Meiwei Wang, Huansheng Yang, Yali Li and Shuai Chen analyzed the data and prepared tables and figures. Meiwei Wang, Lixia Wang, Lanmei Yin and Shanping He prepared the manuscript.

\section{Conflicts of interest}

The authors have no conflicts of interest.

\section{Acknowledgements}

This study was supported by the Hunan Science and Technology Project (2017XK2020), the Xiaoxiang Scholar Distinguished Professor Fund of Hunan Normal University, the National Thousand Young Talents Program and the Hunan Hundred Talents Program.

\section{References}

1 V. Sosa, T. Moliné, R. Somoza, et al., Oxidative stress and cancer: an overview, Ageing Res. Rev., 2013, 12, 376-390.

2 J. M. C. Gutteridge and B. Halliwell, Mini-review: oxidative stress, redox stress or redox success?, Biochem. Biophys. Res. Commun., 2018, 502(2), 183.

3 J. L. Duan, J. Yin, W. K. Ren, T. Liu, et al., Dietary supplementation with L-glutamate and L-aspartate alleviates oxidative stress in weaned piglets challenged with hydrogen peroxide, Amino Acids, 2016, 48, 53-64.

4 H. Xiao, M. M. Wu, F. Y. Shao, et al., N-Acetyl-L-cysteine protects the enterocyte against oxidative damage by modulation of mitochondrial function, Mediators Inflammation, 2016, 2016, 8364279.

5 M. L. Circu and T. Y. Aw, Intestinal redox biology and oxidative stress, Semin. Cell Dev. Biol., 2012, 23, 729-737.

6 J. Yin, J. Duan, Z. Cui, et al., Hydrogen peroxide-induced oxidative stress activates nf-kb and nrf2/keap1 signals and triggers autophagy in piglets, $R S C$ Adv., 2015, 5, 1547915486.

7 F. Biasi, M. Deiana, T. Guina, et al., Wine consumption and intestinal redox homeostasis, Redox Biol., 2014, 2, 795-802.

8 A. Rezaie, R. D. Parker and M. Abdollahi, Oxidative Stress and Pathogenesis of Inflammatory Bowel Disease: An Epiphenomenon or the Cause?, Dig. Dis. Sci., 2007, 52, 2015-2021.

9 A. Thomson, D. Hemphill and K. N. Jeejeebhoy, Oxidative Stress and Antioxidants in Intestinal Disease, Dig. Dis., 1998, 16, 152-158.

10 D. N. Seril, J. Liao, G. Y. Yang and C. S. Yang, Oxidative Stress and Ulcerative Colitis-Associated Carcinogenesis: Studies in Humans and Animal Models, Carcinogenesis, 2003, 24, 353362. 
11 T. Hussain, B. E. Tan, Y. L. Yin, et al., Oxidative stress and inflammation: what polyphenols can do for us?, Oxid. Med. Cell. Longevity, 2016, 2016, 7432797.

12 Y. Martínez, X. Li, G. Liu, et al., The role of methionine on metabolism, oxidative stress, and diseases, Amino Acids, 2017, 49, 2091-2098.

13 X. H. Zhou, L. Q. He, C. Wu, et al., Serine Alleviates Oxidative Stress via Supporting Glutathione Synthesis and Methionine Cycle in Mice, Mol. Nutr. Food Res., 2017, 1700262.

14 J. A. Farrington, M. Ebert, E. J. Land, et al., Bipyridylium quaternary salts and related compounds. V. Pulse radiolysis studies of the reaction of paraquat radical with oxygen. Implications for the mode of action of bipyridyl herbicides, Biochim. Biophys. Acta, Bioenerg., 1973, 314, 372-381.

15 D. X. Yuan, T. Hussain, B. Tan, et al., The evaluation of antioxidant and anti-inflammatory effects of Eucommia ulmoides flavones using diquat-challenged piglet models, Oxid. Med. Cell. Longevity, 2017, 2017, 1-9.

16 J. Yin, M. Liu, W. K. Ren, J. L. Duan, et al., Effects of dietary supplementation with glutamate and aspartate on diquatinduced oxidative stress in piglets, PLoS One, 2015, 10, e0122893.

17 K. T. Chung, T. Y. Wong, C. I. Wei, et al., Tannins and Human Health: A Review, Crit. Rev. Food Sci. Nutr., 1998, 38, 421-464.

18 G. Ilhami, Z. Huyut, M. Elmastas and H. Aboul-Enein, Radical scavenging and antioxidant activity of tannic acid, Arabian J. Chem., 2010, 3, 43-53.

19 H. M. Appel, Phenolics in ecological interactions: the importance of oxidation, J. Chem. Ecol., 1993, 19, 1521-1552.

20 G. K. B. Lopes, H. M. Schulman and M. Hermes-Lima, Polyphenol tannic acid inhibits hydroxyl radical formation from Fenton reaction by complexing ferrous ions, Biochim. Biophys. Acta, Bioenerg., 1999, 1472, 0-152.

21 T. Basu, S. Panja, A. K. Shendge, et al., A natural antioxidant, tannic acid mitigates iron-overload induced hepatotoxicity in Swiss albino mice through ROS regulation, Environ. Toxicol., 2018, 33, 603-618.

22 O. O. Hamiza, M. U. Rehman, M. Tahir, et al., Amelioration of 1,2 Dimethylhydrazine (DMH) induced colon oxidative stress, inflammation and tumor promotion response by tannic acid in Wistar rats, Asian Pac. J. Cancer Prev., 2012, 13, 4393-4402.

23 B. S. Diana, V. Kubale, S. Martin, et al., Effect of hydrolysable tannins on intestinal morphology, proliferation and apoptosis in entire male pigs, Arch. Anim. Nutr., 2016, 70, $1-11$.

24 H. S. Yang, F. Wu, L. N. Long, et al., Effects of yeast products on the intestinal morphology, barrier function, cytokine expression, and antioxidant system of weaned piglets, $J$. Zhejiang Univ., Sci., B, 2016, 17, 752-762.

25 H. S. Yang, X. Xiong, X. Wang, et al., Effects of weaning on intestinal crypt epithelial cells in piglets, Sci. Rep., 2016, 6, 36939.
26 K. T. Chung, C. I. Wei and M. G. Johnson, Are tannins a double-edged sword in biology and health?, Trends Food Sci. Technol., 1998, 9, 168-175.

27 S. H. Lee, P. L. Shinde, J. Y. Choi, et al., Effects of tannic acid supplementation on growth performance, blood hematology, iron status and faecal microflora in weanling pigs, Livest. Sci., 2010, 131, 281-286.

28 G. Mariscal-Landín, J. H. Avellaneda, T. D. Souza, et al., Effect of tannins in sorghum on amino acid ileal digestibility and on trypsin and chymotrypsin activity of growing pigs, Anim. Feed Sci. Technol., 2004, 117, 245-264.

29 G. Biagi, I. Cipollini, B. R. Paulicks, et al., Effect of tannins on growth performance and intestinal ecosystem in weaned piglets, Arch. Anim. Nutr., 2010, 64, 121-135.

30 P. Zheng, B. Yu, J. He, et al., Arginine metabolism and its protective effects on intestinal health and functions in weaned piglets under oxidative stress induced by diquat, Br. J. Nutr., 2017, 117, 1-8.

31 S. Mitjavila, C. Lacombe, G. Carrera, et al., Tannic Acid and Oxidized Tannic Acid on the Functional State of Rat Intestinal Epithelium, J. Nutr., 1977, 107, 2113-2121.

32 J. M. Dawson, P. J. Buttery, D. Jenkins, et al., Effects of dietary quebracho tannin on nutrient utilisation and tissue metabolism in sheep and rat, J. Sci. Food Agric., 1999, 79, 1423-1430.

33 J. J. Lu, X. T. Zou and Y. M. Wang, Effects of sodium butyrate on the growth performance, intestinal microflora and morphology of weanling pigs, Rocz. Nauk Roln., Ser. B, 2008, 17, 568-578.

34 M. Barszcz, M. Taciak and J. Skomial, A dose-response effects of tannic acid and protein on growth performance, caecal fermentation, colon morphology, and betaglucuronidase activity of rats, Rocz. Nauk Roln., Ser. B, 2011, 20, 613-625.

35 J. C. Isenburg, N. V. Karamchandani, D. T. Simionescu and N. R. Vyavahare, Structural requirements for stabilization of vascular elastin by polyphenolic tannins, Biomaterials, 2006, 27, 3645.

36 E. Bouki, V. K. Dimitriadis, M. Kaloyianni, et al., Antioxidant and pro-oxidant challenge of tannic acid in mussel hemocytes exposed to cadmium, Mar. Environ. Res., 2013, 85, 13-20.

37 R. Kohen and A. Nyska, Oxidation of Biological Systems: Oxidative Stress Phenomena, Antioxidants, Redox Reactions, and Methods for Their Quantification, Toxicol. Pathol., 2002, 30, 620-650.

38 W. A. Solis, P. T. Dalton, M. Z. Dieter, et al., Glutamatecysteine ligase modifier subunit: mouse Gclm, gene structure and regulation by agents that cause oxidative stress, Biochem. Pharmacol., 2002, 63, 1739-1754.

39 M. Kobayashi and M. Yamamoto, Molecular Mechanisms Activating the Nrf2-Keap1 Pathway of Antioxidant Gene Regulation, Antioxid. Redox Signaling, 2005, 7, 385-394.

40 R. Howden, Nrf2 and Cardiovascular Defense, Oxid. Med. Cell. Longev., 2013, 1, 104308. 
41 T. Suzuki, H. Motohashi and M. Yamamoto, Toward Clinical Application of the Keap1-Nrf2 Pathway, Trends Pharmacol. Sci., 2013, 34, 340-346.

42 Q. Ma, Role of Nrf2 in Oxidative Stress and Toxicity, Annu. Rev. Pharmacol. Toxicol., 2013, 53, 401-426.

43 J. W. Kaspar, S. K. Niture and A. K. Jaiswal, Nrf2:Inrf2 (Keap1) Signaling in Oxidative Stress, Free Radic. Biol. Med., 2009, 47, 1304-1309.

44 J. Wang, L. M. Zeng, B. E. Tan, et al., Developmental changes in intercellular junctions and $\mathrm{Kv}$ channels in the intestine of piglets during the suckling and post-weaning periods, $J$. Anim. Sci. Biotechnol., 2016, 7, 1-10.
45 J. Yin, J. L. Duan, Z. J. Cui, et al., Hydrogen peroxide-induced oxidative stress activates NF-kappa B and Nrf2/Keap1 signals and triggers autophagy in piglets, $R S C A d v$., 2015, 5(20), 15479-15486.

46 D. G. Song, Y. Cheng, X. Li, et al., Biogenic Nanoselenium Particles Effectively Attenuate Oxidative Stress-Induced Intestinal Epithelial Barrier Injury by Activating the Nrf2 Antioxidant Pathway, ACS Appl. Mater. Interfaces, 2017, $7 \mathrm{~b} 03377$.

47 J. Yin, M. Liu, W. Ren, et al., Effects of dietary supplementation with glutamate and aspartate on diquatinduced oxidative stress in piglets, PLOS One, 2015, 10, e0122893. 